DOI https://doi.org/10.36059/978-966-397-113-1/322-345

\title{
LEGAL STATUS OF POLITICAL PARTIES IN UKRAINE: PROBLEMS
}

\section{Fedorenko V. L.}

\section{INTRODUCTION}

The publication deals with the actual problems of the theory and practice of formation and development of the legal status of political parties in Ukraine, taking into account the positive foreign experience. It is noted that today, particular importance is acquired in national political systems in the countries with parliamentary and parliamentarypresidential governance form. In Great Britain, Italy, Spain, Canada, Germany, Japan and many other states, it is political parties that form parliamentary coalitions and form governments that are called upon to implement the political programs of the members of the parliamentary majority.

The genesis of political parties in Ukraine, in the context of the experience of the political and legal systems of the states of Europe and North America, is explored. It is noted that, despite the long-standing sources, political parties, in their modern sense, appeared in the 19th century. There were the following conditions for their approval: to consolidate in the first constitutions and constitutional acts the rights of citizens to political associations and the right to elect and be elected to parliaments and local legislatures, as well as with the development of modern parliamentarism and the adoption of ideas of civilian control over public authorities. It was during this period that the parties began to legitimately transform their political goals into real political power by the results of parliamentary elections. The first of these were the European liberal parties of the late 19 th century.

On the eve of the World War II, a significant number of political parties of a chiefdom nature are being established in the states of Europe. As for the latter, one should mention the CPSU in the former USSR, the National Fascist Party (PNF) in Italy, the NSDAP in Nazi Germany, the Spanish Phalanx in Spain, the Christened Arrows party in Hungary, etc. 
A similar landscape of political parties in that time in Europe became one of the preconditions of the World War II.

At the end of 20th century, there were many types and types of parliamentary and extra-parliamentary parties in the world. In particular, V. Beym distinguished the following among them: (1) conservatives; (2) liberals and radicals; (3) social democrats and socialists; (4) agrarians; (5) ethnic and religious parties; (6) Christian democrats and protestants; (7) communists; (8) fascists; (9) the parties of the bourgeois opposition; and (10) the environmental movements, etc. ${ }^{1}$

At the end of 20th-21st centuries, mass political parties appeared in the countries of Central and Eastern Europe. It led to the destruction of the communist regimes (Lithuania, Poland, Ukraine and Czech Republic, etc.), but soon they lost their polarity and disappeared from the political landscape of these states. An example of such an influential political force was the People's Movement of Ukraine (1988).

During the 28 years of Independence of Ukraine, the party political system suffered serious transformations and now, as of January 1, 2019, it is represented by 352 parliamentary and extra-parliamentary political parties, including such popular after the regular elections of the President of Ukraine in 2019 as the Servant of the People party (The political party registered under No. 377 dated March 31, 2016). At the same time, in 2014-2019, the number of political parties in Ukraine grew by one third.

Summarizing the provisions of the law and the views of scholars of law, it is possible to determine that a political party (from the Latin. pars means 'part'; plural form: partes means 'parties') it is organized on the principles of voluntariness and equality of the community (association) of citizens, united by a common political ideology and legalized by the state in the established manner, which aims at gaining political power in the state through participation in democratic elections and the realization of its political ideology in the internal and foreign policy of the state.

In turn, the functions of political parties are the main directions and types of their influence on society and the state with a view to comprehensively realizing their party political ideology and program at the national level. At the same time, the main functions of political parties in Ukraine, in our opinion, are as follows: the formation and

\footnotetext{
${ }^{1}$ Демократизация : учебн. пособ. / сост. и науч. ред. : К. В. Харпфер, П. Бернхаген, Р. Ф. Инглхарт, К. Вельцель ; пер. с англ. под науч. ред. М. Г. Миронюка ; предисл., сост. указателя М. Г. Миронюка ; Нац. исслед. ун-т «Высшая школа экономики». - М. : Изд. дом Высшей школы экономики, 2015. - С. 353.
} 
implementation of a certain political ideology and program; development and diversification of the national political system; participation in national and local elections in order to ensure the representation of parties in elective bodies and elected positions; the formation of legislative and other normative project initiatives that embody the program goals and objectives of the political party; establishment and protection of political rights and freedoms of citizens; substantiation and advocacy of political views alternative to the pro-government; political control over the activities of the ruling parliamentary coalition, as well as the activities of the prime minister and the government; interaction with other political parties and public organizations on issues of political activity, etc.

By their legal nature, political parties are non-profit organizations $(N P O)$. At the same time, they have the right to own, use and dispose of movable and immovable property, have bank accounts, transport and lease premises, etc. Not infrequently, political parties have intellectual property: political programs, books and party symbols, etc.

In the EU, virtually all states have this mechanism to prevent political corruption. More and more post-Soviet republics (Georgia, etc.) are introducing state funding for political parties. Starting in 2016, this mechanism for preventing political corruption is active in Ukraine and shows some success.

\section{Parties in political and legal systems of the 21st century}

Political parties are an important component of the political and legal systems and the constitutional order of most modern states of the world, including Ukraine. Multipartyism has become an important feature of the democratization of political and legal processes, even in the smallest states in Europe, with the exception of the Vatican. For example, the following are valid within Andorra political party: Liberal Party of Andorra, the Social Democratic Party of Andorra, Greens of Andorra; the Independent, the Patriotic Union, the Free List progressive civic party in Liechtenstein; the Christian-Social People's Party, the Luxembourg Socialist Workers' Party, the Communist Party of Luxembourg, the Lefts, and the Democratic Parties in Luxembourg ${ }^{2}$.

\footnotetext{
2 Политические партии мира : энциклопедический справочник ; под общ. ред. Я.А. Пляйса, А.Б. Шатилова. - М. : Полтитическая энциклопедия, 2017. - С. 19-20, 88-91.
} 
In democratic states, political parties become genuine 'fraudsters of personnel' for the administrations of the heads of state or prime ministers and their governments. Not infrequently, the leaders of modern states are associated with political forces that have brought them to the highest positions in the states. Thus, today Truman is not the US President only, but also the leader of the Republican Party of America, A. Merkel is the Chancellor of Germany and leader of the Christian Democratic Union, E. Macron is the President of France and leader of the Forward! political party. Newly elected in April 2019, the President of Ukraine V. Zelenskyi is leader of the Servant of the People party.

In the 21 st century, contemporary thinkers are increasingly reminded of the optimism of F. Fukuyama, who in his world-famous work, The End of History and the Last Man (1989), predicted that the consolidation of democracy in the post-Soviet and post-socialist countries was a world liberal revolution', which led to '...Universal History, which leads towards a liberal democracy'. ${ }^{3}$ Unfortunately, today the ideas of liberal democracy in Europe, North America and other regions of the world are experiencing their own crisis. It also affected the development of the party democracy of modern states, including the states of Europe.

As the well-known Irish thinker P. Mayer wrote in his Introduction to the Managing the Emptiness: The Blurring of Western Democracy (2011) paper:

'The era of party democracy has passed. Despite the fact that the parties themselves continue to work, they have lost their connection with the society and participate in such a futile competition that they are no longer capable of securing the preservation of democracy in its present form, ${ }^{4}$.

The popularity of such views is also confirmed by the content of the Manifesto of European Patriots as The European House of Fire, in which liberal democracy is opposed to populism, and states that '... With this lazy Europe, without elasticity and thought, we must say goodbye. We have no choice. When populism is raging, we must strive for Europe, otherwise we will drown under its waves...5. This position of the

\footnotetext{
${ }^{3}$ Фукуяма Ф. Конец истории и последний человек / Фрэнсис Фукуяма ; пер. с англ. М. Б. Левина. М. : Изд-во «АСТ», 2015. - С. 90-91.

4 Майр П. Управляя пустотой: размывание западной демократии / Питер Майр; пер. с англ. Д. Маткиной, А. Новикова, И. Соболевой, В. Степановой. - М.: Изд-во Института Гайдара, 2019. - С. 19.

5 Маніфест європейських патріотів «Європейський дім у вогні». Електронний ресурс. Режим доступу: http://www.ji-magazine.lviv.ua/2019/europejskyj-dim-u-vogni.htm - назва з екрану.
} 
European liberal democracies is, in essence, an appeal to the return of the values of liberalism, in particular, to the classical party and political systems that are now replaced by populist social movements, etc.

At the same time, despite the pessimism of individual scholars and experts on the future of political parties during the crisis of liberal democracy in Europe, they remain an important component of the political and legal systems and the subject of constitutional law. Particular importances in the national political systems are the parties in the states with parliamentary and parliamentary and presidential governance forms. In these states, it is the political parties that form parliamentary coalitions and form governments that are called upon to implement the political programs of the members of the parliamentary majority. This is the content and logic of the parliamentary and governmental political systems of Great Britain, Italy, Spain, Canada, Germany, France, Japan and many other countries of the world.

Political parties cannot be considered part of the state, since, with the exception of the DPRK and some other countries of the world, political positions in democratic states are separated from administrative ones. At the same time, it is difficult to attribute political parties to civil society without reservations, since their main goal is the struggle for political power in the state. All this, as well as the historical experience of becoming and development, predetermines the special legal status of political parties in Ukraine and abroad.

\section{Genesis of Legal Status of Political Parties in Ukraine and Located Abroad}

Prototypes of political parties, according to M. Duverger, can be found in the Senate of Antique Rome, and in the Sejm of the PolishLithuanian Commonwealth (The United Commonwealth of the Kingdom of Poland and the Grand Duchy of Lithuania). Another scientist J. Osborne sees the origins of the first parties in the experience of association of the guilds of the Italian cities (Bologna, Milan, Florence, etc.) in the quarterly self-defence that defended the interests of the Polans (from Popolo means 'the people') before the aristocracy in the 13th century ${ }^{6}$. Instead, K. Gojiev writes about the germs of the first parties in

\footnotetext{
${ }^{6}$ Осборн Р. Цивилизация. Новая история Западного мира / Р. Осборн ; пер. с англ. М. Колопотина. - М. : Изд-во АСТ, 2018. - С. 285-286.
} 
the medieval Italian principalities, where the Guelphs defended the interests of the trade and artisans, and the Ghibellines as the interests of the nobles and feudal lords, and finds them among the Arminians and Gomarists in the Netherlands and among Educators and Independents in England in the 17 th century ${ }^{7}$.

In his time, A. de Tocqueville in his On Democracy in America work wrote that after the War of Independence in America in the 18th century, there were two parts of the nation: one part tried to limit the power of the people, and the second part to infinitely extend it. This became the basis for the emergence of various large and small political parties.

'The big parties are hitting French society, it will incite; the first of them break it into pieces, the latter eradicate it; large parties, shaking society, thus largely rescue it, and small, without apparent benefit, sow disagreement', wrote A. de Tocqueville ${ }^{8}$.

However, until the 19th century, in the absence of parliamentary and governmental state systems in their modern sense, political parties did not exist in their modern sense. In this case, situational political groupings in representative bodies cannot be considered a political group of parlament: between them there are differences, typical for spontaneous and organized phenomena'.

Political parties, in their modern sense, appeared in the 19th century, in the context of consolidating the rights of citizens to political associations and the right to elect and be elected, as well as with the development of modern parliamentarism and the adoption of the ideas of civil society as 'the controller' of the state in the first constitutions and constitutional acts.

It was during this period that the parties began to legitimately transform their political goals into real political power by the results of parliamentary elections. The first of these was the European liberal parties of the late 19th century, which substantiated the liberal ideology and created their factions in parliaments. Among such liberal parties were the Liberal Party of Great Britain, the Progressive Party in Germany, the Belgian Liberal Party, and others.

\footnotetext{
${ }^{7}$ Гаджиев К.С. Введение в политическую науку / К.С. Гаджиев : учебн. ; изд. 2-е, перераб. и доп. М. : Издат. корпорац. «Логос», 1997. - С. 162-163.

${ }^{8}$ Токвіль А. де. Про демократію в Америці. У двох томах / А. де Токвіль ; пер. $з$ фр. Г. Філіпчука та М. Москаленка : передм. А. Жардена. - К. : Вид. дім «Всесвіт», 1999. - С. 151.

9 Дюверже М. Политические партии / М. Дюверже ; пер. с франц. ; изд. 4-е. - М. : Академ. Проект; Трикста, 2007. - С. 22-23.
} 
At the end 19th - early 20th centuries, the first petty-bourgeois political parties were formed in Ukraine, among the university intelligentsia of Kyiv, Kharkiv, Lviv, Poltava, Chernihiv and Odessa. Thus, in 1890, the first Russian-Ukrainian Radical Party (RURP) was founded in Lviv, in Ukraine, whose founders were I. Franko, M. Pavlyk and others and in 1896, a leading political party of Galicia was formed the Ukrainian National Democratic Party (UNDP) ${ }^{10}$.

In 1900, the Revolutionary Ukrainian Party (RUP) was founded in Kharkiv, the program document of which was the Independent Ukraine work of M. Mikhnovskyi's lawyer. In 1902, a group of radicals led by M. Mikhnovskyi broke away from RUP and created the Ukrainian National Party (UNP), and in 1904, the Ukrainian Social and Democratic Party was separated from RUE. And in 1905, the Party of People's Freedom constitutional-democratic was created in Kyiv. At the same time, in 1903, the Russian Social-Democratic Revolutionary Party (the RSDRP pro-Russian party) was formed. At the same time, most Ukrainian parties were able to prove themselves in power and political activity only during the period of national liberation struggles of the UNR-ZUNR era ${ }^{11}$.

In the 20th century, political parties have gained popularity both in states with democratic, and with undemocratic regimes. On the eve of the World War II, a significant number of political parties of a chiefdom nature are being established in the states of Europe. As for the latter, one should mention the CPSU in the former USSR, the National Fascist Party (PNF) in Italy, the NSDAP in Nazi Germany, the Spanish Phalanx in Spain and the Christened Arrows party in Hungary, etc. These political parties were the only or monopolistic dominant in the mentioned states.

As to the threats of one-party states for democracy, the famous American historian T. Snyder wrote the following:

'The parties that recaptured the state and suppressed the rivals were not at all almighty from the outset. They used the historical moment to exclude their options from political life. Therefore, you need to support a multi-party system and protect the democratic election processes ${ }^{12}$.

\footnotetext{
10 Федоренко В.Л. Конституційне право України : підручник ; До 20-ої річниці Конституції України та 25-ої річниці незалежності України / В.Л. Федоренко. - К. : Вид-во «Ліра», 2016. - С. 196.

11 Федоренко В.Л. Конституційне право України : підручник ; До 20-ої річниці Конституції України та 25-ої річниці незалежності України / В.Л. Федоренко. - К. : Вид-во «Ліра», 2016. - С. 197.

${ }^{12}$ Снайдер Т. О тирании: 20 уроков ХХ века / Т. Снайдер; пер. с англ. Н. Охотина. - М. Изд-во ACT : CORPUS, 2018. - C. 29.
} 
It is obvious that a similar landscape of political parties in that time became one of the preconditions of World War II, because the ideology of these parties quickly exhausted the attractiveness of the countries, since its leaders, after coming to power, restructured the totalitarian states. Therefore, the war was considered by the leaders of the mentioned political parties as a way of mobilizing the nation and continuing domestic policy on the international scene.

The corresponding tendency in the development of political parties has also developed in the national liberation movement of Ukraine. Thus, in 1940, the division of the Organization of Ukrainian Nationalists (OUN) into two ideological wings took place: supporters of S. Bandera and sympathizers of A. Melnyk ${ }^{13}$.

In the post-war period, the ideological palette of political parties in the states of Europe, with the exception of the former USSR and the socalled 'the socialist camp' (Albania, Bulgaria, the GDR, Poland, SFRY, Romania, Hungary and Czechoslovakia, etc.) and Spain during the Franco dictatorship expanded considerably. The political parties of the liberaldemocratic and social-democratic directions have gained considerable popularity.

At the end of 20th century, there were many types and types of parliamentary and extra-parliamentary parties in the world. In particular, V. Beym distinguished the following among them: (1) conservatives; (2) liberals and radicals; (3) social democrats and socialists; (4) agrarians; (5) ethnic and religious parties; (6) Christian democrats and protestants; (7) communists; (8) fascists; (9) the parties of the bourgeois opposition; and (10) the environmental movements, etc ${ }^{14}$.

At the same time, the undeniable achievement of the constitutional law of the second half of the 20th century became the regulation of the legal status of political parties in the constitutions and other acts of the current constitutional legislation. Thus, the Basic Law of the Federal Republic of Germany (FRG) (Art. 21), the Spanish Constitution (Art. 6), the Italian Constitution (Art. 40), the Polish Constitution (Art. 11), the

\footnotetext{
${ }^{13}$ Мірчук П. Акт відновлення Української державности 30. червня 1941 року: його генеза та політичне й історичне значення / П. Мірчук. - Ню Йорк : Видання Головної Управи Організації Оборони Чотирьох Свобід України, 1952. - С. 8.

14 Демократизация : учебн. пособ. / сост. и науч. ред. : К. В. Харпфер, П. Бернхаген, Р. Ф. Инглхарт, К. Вельцель ; пер. с англ. под науч. ред. М. Г. Миронюка ; предисл., сост. указателя М. Г. Миронюка ; Нац. исслед. ун-т «Высшая школа экономики».- М. : Изд. дом Высшей школы экономики, 2015. - С. 353.
} 
French Constitution (Art. 4) and others secured the right of citizens to freely unite in political parties.

So, for example, the Italian Constitution in Art. 40 stipulates: 'All citizens have the right to unite in a party in a democratic manner in order to participate in the definition of a national policy ${ }^{, 15}$. And the Constitution of Poland in Art. 11 stipulates the duty of the state to provide '... the formation and activities of political parties', whose activities stipulate '... on the principles of voluntariness and equality, to unite Polish citizens in order to influence democratic methods in shaping the state policy ${ }^{16}$.

In 1967, the FRG adopted the world's first special law on political parties. Currently, the Law on Political Parties in the wording of 2002 acts in this state ${ }^{17}$.

Instead, in Ukraine, which for a long time was part of the former USSR, there was a rather specific constitutional regulation of the activities of political parties, which was conditioned by a one-party system. So, in the Constitution of the USSR in 1978, there was a notorious Article 6:

'The Communist Party of the Soviet Union is the governing and steering force of Soviet society, the nucleus of its political system, state and public organizations. The CPSU exists for the people and serves the people ${ }^{18}$.

The CPSU monopoly on political activity had detrimental consequences for the development of the political, socio-economic and humanitarian system of Ukraine within the former USSR.

After the proclamation of the Declaration on State Sovereignty of Ukraine in our country, the processes of party building were started. Thus, already on November 5, 1990, the Ministry of Justice registered the first political party in an independent Ukraine as the Ukrainian Republican Party, one of whose leaders was the legendary dissident, the Hero of Ukraine L. Lukianenko. In 1991, the Party of the Greens of Ukraine, the Ukrainian Democratic Party, the Democratic Party of Ukraine, the

\footnotetext{
15 Конституція Італійської Республіки (з перед. В. Шаповала) / В. Шаповал. - К. : Москаленко О.М., 2018. - С. 30.

${ }^{16}$ Конституція Польської Республіки (з перед. В. Шаповала) / В. Шаповал. - К. : Москаленко О.М., 2018. - C. 17.

17 Achtes Gesetz zur Änderung des Parteiengesetzes vom 29. Juni 2002 // Bundesgesetzblatt. - Teil I. 2002. - № 42. - S. 2268-2276.

${ }^{18}$ Конституції і конституційні акти України. Історія і сучасність. 3-є вид. ; упоряди. І.О. Кресіна, О.В. Батанов ; відп. ред. Ю.С. Шемшученко. - К. : Вид-во «Юридична думка», 2011. - С. 123.
} 
People's Party of Ukraine, the Liberal Party of Ukraine, the Social Democratic Party of Ukraine, the United Social-Democratic Party of Ukraine, the Ukrainian Christian Democratic Party of Ukraine and the Socialist Party of Ukraine. At the same time, the People's Movement of Ukraine (PMU) retained the actual status of mass public movement. And already in 1996, the Constitution of Ukraine in Art. 36 has consolidated the right of citizens to '... freedom of association in political parties ${ }^{19}$.

The end of 20th-21st centuries was marked by the emergence of mass political parties in the countries of Central and Eastern Europe, which led to the destruction of the communist regimes (Lithuania, Poland, Ukraine and Czech Republic, etc.). But soon their polarity was lost and they disappeared from the political landscape of these states. An example of such an influential political force can be the People's Movement of Ukraine (1988), which in the late half of the 90's of the last century lost its political weight, and after the tragic death in 1999, its leader V. Chornovil lost his party representation in parliament. All other mass political parties of Ukraine (the CPU, the SDPU (u), the For a United Ukraine and the Party of Regions, etc.), widely represented in the Verkhovna Rada of Ukraine I-VI convocations, were short-lived. None of these forces were elected into the Parliament of the VIII convocations after the 2014 Dignity Revolution.

Two Ukrainian revolutions of the 21 st century have also become an important factor in the development of the party-political system and the mechanism for the implementation and protection of the right of citizens to participate in the activities of political parties, which stimulated the revival of the authority of political parties in society through the strengthening of the parliamentary component in the mechanism of government. ${ }^{20}$ Thus, the result of the 2004 Orange Revolution, which the famous Ukrainian thinker and patron B. Havrylyshyn called 'one of the most important, most noble events in the history of Ukraine ${ }^{21}$, was the introduction of a parliamentary and presidential governance form and the

\footnotetext{
${ }^{19}$ Конституція України : прийнята на п’ятій сесії Верховної Ради України 28 червня 1996 року // Відомості Верховної Ради України. - 1996. - № 30. - Ст. 141.

${ }^{20}$ Fedorenko W. Problem ochrony praw człowieka w warunkach rewolucji oraz konfliktów wojennych / W. Fedorenko // Ochrona praw człowieka w wymiarze uniwersalnym. Akcjologia -instytucje - nowe wyzwania - praktyka. Red Naukowa J. Jaskernia, K. Sprzyszak. - Toruń: Wydawnictwo Adam Marszałek, 2017. - S. 74-78.

${ }^{21}$ Гаврилишин Б. До ефективних суспільств: Дорога в майбутнє; доповідь Римському Клубові / Б. Гаврилишин ; упорядник В. Рубцов. - Вид. 4-е. К. : Унів. Вид-во ПУЛЬСАРИ, 2013. - С. 237.
} 
introduction of a proportional (party) electoral system in 2006 in the election of people's deputies of Ukraine.

A decade later, the Revolution of Dignity was due to the revival of the parliamentary and presidential republican governance form. However, the maintenance of the majority-proportional system during the election of people's deputies of Ukraine and local elections, even with the increase in the number of political parties from 109 political parties in $2001^{22}$ to more than 350 now, somewhat narrower prospects for the development of the Ukrainian Party Political System. Political discourse on returning to a proportional electoral system in the formation of the parliament remains relevant to this day.

The Party Political System has been suffered serious transformations during the 28 years of independence of Ukraine. Now, as of January 1, 2019 , it is represented by 352 parliamentary and extra-parliamentary political parties, including such popular after the regular elections of the President of Ukraine in 2019 as the Servant of the People party (The political party was registered under No. 377 dated March 31, 2016) ${ }^{23}$. At the same time, in 2014-2019, the number of political parties in Ukraine grew by one third.

In all these cases, the organization and activities of political parties, the development of party political systems and the provision of party representation in parliaments were the consequence and result of citizens' realization of their right to unite into political parties. In accordance with Part 1 of Art. 36 of the Basic Law, Ukrainian citizens are united in political parties in order to satisfy their political rights and interests. ${ }^{24}$ Thus, it is the citizens themselves who are the main founders of political parties and the political system of Ukraine as a whole.

\section{Political Parties: Concepts and Functions}

In legal science, various, often diametrically opposed, definitions of the category 'political party' are widespread. In the Soviet era in the Encyclopaedia of State and Law (1925-1927), V. Adoratskyi characterized the political party as '...organizations for the struggle for

\footnotetext{
${ }^{22}$ Див. : Політичні партії в Україні: інформаційно-довідкове видання / Я. Давидович (голова ред. колегії). - К.: Атіка, 2005. - 440 с.

${ }^{23}$ Політичні партії / Офіційний веб-сайт Міністерства юстиції України. Електронний ресурс. Режим доступу : https://minjust.gov.ua/m/4561 - назва з екрана.

${ }^{24}$ Конституція України : прийнята на п’ятій сесії Верховної Ради України 28 червня 1996 року // Відомості Верховної Ради України. - 1996. - № 30. - Ст. 141.
} 
political power: for gaining power or for its maintenance ${ }^{, 25}$. This statement reproduced the so-called 'Class approach' to understanding the state and society in the former USSR. But monopoly systems of totalitarian states of the 20th century, as already noted earlier, cannot be considered as a positive example of the development of political systems of the present.

At one time, one of the ideologues of liberalism L. von Mises wrote the followings:

'In a state system only, when all citizens enjoy equal rights, in accordance with liberal ideals, which never and never have been fully achieved, there can be political parties that consist of people who are united by the desire to realize their ideas in the field of law and public administration, 26 .

Similar political and legal views, after the proclamation of Ukraine's independence, were widely disseminated both in Ukrainian constitutional and legal opinion, as well as in the Constitution and laws of Ukraine.

At one time, V. Melashchenko wrote that the political party is as follows: '... the association of citizens as the supporters of a certain national program of social development, the main purpose of which is participation in the development of state policy, the formation of authorities, local and regional self-government and representation in their composition, 27.

Another scientist-constitutionalist Yu. Todyka noted that for the political parties in Ukraine, the legislator created the conditions under which they act as active participants in the state-legal relations in the electoral process, in other spheres of political and legal relations ${ }^{28}$. According to N. Bohasheva, a political party should be defined as an association of citizens, whose main purpose is to participate in democratic elections to state authorities by nominating candidates for such elections ${ }^{29}$. Both O. Sovhyria and N. Shuklina wrote that political parties in Ukraine

\footnotetext{
25 Адоратский В. Партия / В. Адоратский // Энциклопедия государства и права ; под ред. П. Стучки, в 3-х томах. - Т. 3. - М. : Изд-во Коммунистической Академии, 1925-1927. - С. 238.

${ }^{26}$ Мизес фон Л. Либерализм / Людвиг фон Мизес; пер. с англ. и комментарии А.В. Куряева. - М.; Челябинск: Социум, 2019. - С.169.

${ }^{27}$ Мелащенко В. Ф. Основи конституційного права України : курс лекцій для студ. юрид. вузів і факультетів / В. Ф. Мелащенко. - К. : Вентурі, 1995. - С. 58-59.

${ }_{28}$ Тодыка Ю. Н. Конституционное право Украины : отрасль права, наука, учебная дисциплина : учебн. пособ. - Х. : «Фолио», «Райдер», 1998. - С. 117-118.

29 Богашева Н.В. Відносини держави і політичних партій в Україні: конституційно-правові аспекти : монограф. / Н.В. Богашева. - К. : Логос, 2012. - С. 57.
} 
'... contribute to the formation and expression of the political will of the citizens, and participate in the elections ${ }^{30}$. Justices justify other values of this category.

Definition of political parties is also found in international documents. For example, in the Codex of Good Practice for Political Parties adopted by the Venice Commission in 2008, it is stated that a political party is an association whose task is to nominate candidates for elections in order to be represented in political institutions and to exercise political power for any level: national, regional or local, or at all at once ${ }^{31}$.

The category 'political party' is regulated in the current legislation. Thus, Art. 2 of the Law of Ukraine On Political Parties in Ukraine stipulates the followings: 'A political party is a voluntary association of citizens who are adherents of a certain national program of social development registered in accordance with the law and whose purpose is to promote the formation and expression of the political will of citizens, participate in elections and other political events ${ }^{32}$.

The generalization of the above definitions and prescriptions can justify the following definition. A political party (from the Latin 'pars' means 'part'; plural form: partes means 'parties') is organized on the principles of voluntariness and equality of the community (association) of citizens, united by a common political ideology and legalized by the state in the established manner, which aims at gaining political power in the state through participation in democratic elections and the realization of its political ideology in the internal and foreign policy of the state.

Their goals and tasks political parties are embodied first of all in functions as the main directions of activity of political parties. So, American scholars believe that political parties are implementing the tasks of the peoples with the government and carry out the following four main functions: (1) nomination of candidates for official elected positions; (2) structuring the voting in the elections; (3) promotion of alternative

\footnotetext{
${ }^{30}$ Совгиря О.В., Шукліна Н.Г. Конституційне право України. Повний курс: навч. посібн. - К.: Юрінком Інтер, 2018. - C. 158.

31 Кодекс належної практики щодо політичних партій, ухвалений Венеціанською комісією на 77 пленарній сесії (Венеція, 12-13 грудня 2008 р.) // Вибори та демократія. - 2009. - № 4. - С. 84.

32 Про політичні партії в Україні : Закон України від 5 квітня 2001 р. // Відомості Верховної Ради України. - 2001. - № 23. - Ст. 118.
} 
programs for the government; and (4) coordination of government officials $^{33}$.

Independent study of the functions of political parties was conducted by P. Mayer. The scientist believed that the main function of political parties is '...the integration and mobilization of citizens in the political space, where there is a political struggle ${ }^{34}$. P. Mayer also distinguishes other functions of political parties. This, in particular, includes the following functions: (a) public representation as the expression and association of diverse but close-knit interests in broad political programs of the national level; (b) search of political leaders and selection of candidates for public office (public position); and (c) the formation of parliaments and governments, and so on.

At the same time, P. Mayer concludes that the functions of the parties concerning the representation of the interests of the population are gradually offset, while their '...procedural functions become more and more important and important. ... Traditional mass parties have completely vanished their age, ${ }^{35}$.

Instead, K. Strom reduces the functions of political parties to the following three aspirations: (a) to win votes of voters; (b) to occupy public positions; and (c) to realize its political course ${ }^{36}$. We should also agree with Yu.H. Barabash that political parties are implementing two closely related tasks in their activities: promoting, shaping and expressing the political will of the citizens and participation in elections ${ }^{37}$.

In turn, the functions of political parties are the main directions and types of their influence on society and the state with a view to comprehensively realizing their party political ideology and program at the national level.

33 Трудным путем демократии: процесс государственного управления в США / К. Джанда, Д.М. Бери, Д. Голдман, К.В. Хула ; пер. с англ. - М. : «Российск. полит. энциклопедия» (РОССПЭН), 2006. - С. 237.

34 Майр П. Управляя пустотой: размывание западной демократии / Питер Майр; пер. с англ. Д. Маткиной, А. Новикова, И. Соболевой, В. Степановой. - М.: Изд-во Института Гайдара, 2019. С. 127.

35 Майр П. Управляя пустотой: размывание западной демократии / Питер Майр; пер. с англ. Д. Маткиной, А. Новикова, И. Соболевой, В. Степановой. - М.: Изд-во Института Гайдара, 2019. С. 134-135.

36 Демократизация : учебн. пособ. / сост. и науч. ред. : К. В. Харпфер, П. Бернхаген, Р. Ф. Инглхарт, К. Вельцель ; пер. с англ. под науч. ред. М. Г. Миронюка ; предисл., сост. указателя М. Г. Миронюка ; Нац. исслед. ун-т «Высшая школа экономики».- М. : Изд. дом Высшей школы экономики, 2015. - С. 352.

${ }^{37}$ Барабаш Ю. Нариси з конституційного права / Ю. Г. Барабаш. - Х. : Право, 2012. - С. 42. 
The main functions of political parties in Ukraine, in our opinion, are as follows:

- The formation and implementation of a certain political ideology and program;

- Development and diversification of the national political system;

- Participation in national and local elections in order to ensure the representation of parties in elective bodies and elected positions;

- Formation of legislative and other normative project initiatives that embody the program goals and objectives of the political party;

- Establishment and protection of political rights and freedoms of citizens;

- Substantiation and advocacy of political views alternative to the pro-government;

- Political control over the activities of the ruling parliamentary coalition, as well as the activities of the prime minister and the government;

- Interaction with other political parties and public organizations on political issues;

- Establishment of international cooperation with ideologically related parties of foreign countries;

- Ensuring representation of the party in international representative bodies, in particular in the European Parliament (for the EU member states);

- Hiring (Recruiting) and educating political elites and others ${ }^{38}$.

\section{Public Funding of the Activities of Political Parties in Ukraine}

As we know, by their legal nature, political parties are non-profit organizations (NPO). At the same time, they have the right to own, use and dispose of movable and immovable property, have bank accounts, transport and lease premises, etc. Not infrequently, political parties have intellectual property: political programs, books and party symbols, etc. It is obvious that the sources of the respective property of political parties must be impeccable in terms of the requirements of the current legislation.

\footnotetext{
38 Федоренко В.Л. Конституційне право України : підручник ; До 20-ої річниці Конституції України та 25-ої річниці незалежності України / В.Л. Федоренко. - К. : Вид-во «Ліра», 2016. C. 199-200.
} 
Therefore, the main sources of financial, material and logistical assistance to political parties are as follows:

(1) Contributions in support of the statutory activities of a political party carried out by its members, as well as other natural and legal persons;

(2) Financing of statutory activities of political parties from the state budget in accordance with the procedure established by the current legislation, followed by state control over the development and use of these funds for their intended purpose ${ }^{39}$.

In the opinion of experts, ideally the financing of statutory activities of political parties should be carried out in such proportions: $45 \%$ by the state; $45 \%$ by legal entities; and $10 \%$ by individuals ${ }^{40}$. Although, the optimal model for financing political party activities depends on many factors: the traditions of financing political parties, the forms of government, the type of party political system, and the political culture of citizens, etc.

In the European Union, all countries have this mechanism to prevent political corruption. More and more post-Soviet republics (Georgia, etc.) are introducing state funding for political parties. Ukraine did not become an exception to this rule. So, on October 8, 2015, the Verkhovna Rada of Ukraine adopted rather progressive amendments to the Law of Ukraine On Political Parties in Ukraine in connection with the introduction of annual financing of statutory activities of political parties from the State Budget of Ukraine (Section IV-1: State Financing of Political Parties) ${ }^{41}$.

The said Law became not only a condition for granting Ukraine a 'visa-free regime with EU member states', but also an important element of the legislative mechanism for financing political parties and exercising state control over their activities. It came into force on January 1, 2016, in the part of submitting parties' reports on property, income, expenses and financial obligations, and from July 8, 2016 and in part of the introduction of annual state financing of statutory activities of political parties,

\footnotetext{
${ }^{39}$ Про політичні партії в Україні : Закон України від 5 квітня 2001 р. // Відомості Верховної Ради України. - 2001. - № 23. - Ст. 118.

40 Фінансування політичних партій: український та світовий досвід. Основні тези виступу експерта Центру політико-правових реформ 3 конституційного права, виборів та парламентаризму Богдана Бондаренка / Лівий берег/ Електронний ресурс.- Режим доступу: https://lb.ua/blog/education assembly/355836_finansuvannya_politichnih_partiy.html - назва з екрану.

${ }^{41}$ Про політичні партії в Україні : Закон України від 5 квітня 2001 р. // Відомості Верховної Ради України. - 2001. - № 23. - Ст. 118.
} 
reimbursement of party expenses for election campaigning and the establishment of restrictions on the amount of contributions in support of parties by natural persons and legal entities ${ }^{42}$.

Legislation on the financing of political parties in Ukraine imposed restrictions on contributions to statutory activities of political parties. Thus, the Law of Ukraine On Amending Certain Legislative Acts of Ukraine Concerning the Prevention and Counteraction of Political Corruption prohibits the implementation of contributions in support of political parties: (1) state authorities and local self-government bodies; (2) state and communal enterprises, institutions and organizations, as well as legal entities in which not less than ten percent of the authorized capital or voting rights are directly or indirectly owned by the state, local governments or non-residents or ultimate beneficiary owners (controllers) of which are persons authorized to perform functions of the state or local self-government, respectively; (3) foreign states, foreign legal entities, foreigners and stateless persons, as well as legal entities, the ultimate beneficiary owners (controllers) of which are foreigners or stateless persons; (4) unregistered public associations, charitable and religious associations (organizations); (5) citizens of Ukraine who have not attained the age of 18, citizens of Ukraine, which have been declared incapacitated by the court, as well as by anonymous persons or under the pseudonym; (6) other political parties; (7) natural and legal persons with whom an agreement for the purchase of works, goods or services for the needs of the state or a territorial community has been concluded, during the term of such agreement and within one year after its termination, unless the total amount received for such agreement during the term of the agreement and within two years after the termination of its operation does not exceed 10 percent of the total income of a natural or legal person for the relevant period; and (8) natural and legal persons who have an outstanding tax $\operatorname{debt}^{43}$.

In this case, as regards the financing of statutory activities of political parties, only those parties can claim it as follows: '... At the last regular or extraordinary elections of people's deputies of Ukraine, its electoral list

\footnotetext{
${ }^{42}$ Про внесення змін до деяких законодавчих актів України щодо запобігання і протидії політичній корупції : Закон України від 8 жовтня 2015 р. // Відомості Верховної Ради України. - 2015. - № 49-50. Ст. 449.

${ }^{43}$ Про внесення змін до деяких законодавчих актів України щодо запобігання і протидії політичній корупції : Закон України від 8 жовтня 2015 р. // Відомості Верховної Ради України. - 2015. - № 49-50. Ст. 449.
} 
of candidates for deputies in multi-mandate constituency has received at least $2 \%$ of votes from the total number of votes voters cast for all electoral lists of candidates in deputies of Ukraine in multi-mandate constituency $^{44}$.

The decision to grant or not to provide a political party of state financing is taken by the National Agency of Ukraine for the Prevention of Corruption. Although, item 2 of the Transitional Provisions of the Law of Ukraine On Amendments to Certain Legislative Acts of Ukraine on Prevention and Combating Political Corruption contains provisions on financing of those political parties that have overcome the $5 \%$ passing barrier in the last parliamentary elections in 2014.

In 2016, the financing of political parties in Ukraine amounted to UAH 391 million, and spread to 6 parliamentary political parties. However, since the Law of Ukraine On Amendments to Certain Legislative Acts of Ukraine on the Prevention and Combating of Political Corruption of October 8, 2015, entered into part of the state financing of political parties only dated July 1, 2016, political parties received half of the said amount in the $3 \mathrm{rd}$ and the 4th quarter of 2016 only ${ }^{45}$.

Instead, already in 2019, the National Agency on Corruption Prevention (NACP) distributed between the parliamentary political forces a sum of UAH 565,680,500.0, together with funds for the preservation of the gender balance: the People's Front political party (UAH $145,453,400.0$ thousand); the Block of Petro Poroshenko political party (UAH 143,366,100.0 thousand); the Self-Help Union political party (UAH 72, 090.350 thousand); the Opposition Block political party (UAH $61,959,000.0$ ths.); the Radical Party of Oleh Liashko political party (UAH 48,925.70 thousand); and the Batkivshchyna political party (UAH $37,317.900$ thousand). For the preservation of the gender balance, the Self-Help Union party will receive additionally UAH 56,568,050.0 thousand ${ }^{46}$.

\footnotetext{
${ }^{44}$ Про внесення змін до деяких законодавчих актів України щодо запобігання і протидії політичній корупції : Закон України від 8 жовтня 2015 р. // Відомості Верховної Ради України. - 2015. - № 49-50. СТ. 449.

45 Федоренко В.Л. Державне фінансування діяльності політичних партій як чинник розбудови модерної партійно-політичної системи в Україні / В.Л. Федоренко // Вісник НАДУ при Президентові України. Серія «Державне управління». - 2017. - No. 4. - Р. 40-43.

${ }^{46}$ НАЗК розподілило кошти на фінасування політичних партій у 2019 році / Офіційний веб-сайт НАЗК. Електронний ресурс. - Режим доступу: https://nazk.gov.ua/news/nazk-rozpodilylo-koshty-nafinansuvannya-politychnyh-partiy-u-2019-roci - назва з екрану.
} 
In the case of providing state financing for the exercise of statutory activities, a political party is obliged to provide a report on property, income, expenses and financial obligations in accordance with the established term of the current legislation. At the same time, the financial discipline of political parties in Ukraine is subject to control by:

- Accounting Chamber;

- National Agency on Corruption Prevention (NACP).

The powers of the National Agency on Corruption Prevention (NACP) in the area of state control over compliance with statutory restrictions on funding are set out in the Law of Ukraine On Prevention of Corruption of October 14, 2014, with corresponding amendments and supplements $^{47}$.

The experience of financing political parties in Ukraine remains controversial at present. In particular, representatives of the political parties that took part in the last parliamentary elections and collected from $2 \%$ to $5 \%$ (the Freedom, all-Ukrainian Union, and the Public Position, etc.) complain that Government funding solely parliamentary political Parties creating artificial preferences for the past and hinders development of 350 other political parties ${ }^{48}$.

A similar situation is common in the introduction of state funding of political parties as a mechanism to counteract political corruption in most of the states that have decided on this step. According to experts, the success of the relevant reforms in the field of state financing of political parties, on the example of the same Georgia, comes in 8-12 years ${ }^{49}$. However, the assistance of international organizations and projects in the field of the development of democracy and the fight against political corruption gives hope that Ukraine will overcome its path to victory over corruption in the field of building a Democratic Political Party System.

\footnotetext{
${ }^{47}$ Про запобігання корупції : Закон України від 14 жовтня 2014 року // Відомості Верховної Ради України. - 2014. - № 49. - Ст. 2056.

48 Федоренко В.Л. Державне фінансування діяльності політичних партій як чинник розбудови модерної партійно-політичної системи в Україні / В.Л. Федоренко // Вісник НАДУ при Президентові України. Серія «Державне управління». - 2017. - № 4. - С. 42-43.

49 Фінансування політичних партій: український та світовий досвід. Основні тези виступу експерта Центру політико-правових реформ 3 конституційного права, виборів та парламентаризму Богдана Бондаренка / Лівий берег / Електронний ресурс. - Режим доступу: https://lb.ua/blog/education_assembly/ 355836_finansuvannya_politichnih_partiy.html - назва з екрану.
} 


\section{CONCLUSIONS}

The regular election of the President of Ukraine in April 2019 has shown that the national political and legal system, like the political landscape of the EU and other European states, is rapidly changing. In particular, the fatigue of society from traditional political parties and the voters' affinity to alternative, non-systemic parties became noticeable in Ukraine, as in many other European countries. It is expected that this tendency will affect the results of the parliamentary elections in 2019, which will significantly change the centres of political power of parliament and government.

In addition, the reform of local self-government in Ukraine based on decentralization, held in 2014-2019, the foundation of more than 900 United Territorial Communities (UTC) and the expected continuation of the reform of decentralization at the regional level to create the prerequisites for the establishment and development of regional political parties.

There is also a further political de-ideologization of parties in Ukraine, which are increasingly supplanted from the political life of civil society institutions, in particular social networks and social movements. Unlike political parties, which in the inter-electoral period minimize their representation on the ground, and civil society institutions constantly maintain their social activity.

\section{SUMMARY}

The publication deals with the actual problems of the theory and practice of the formation and development of the legal status of political parties in Ukraine and abroad. It is noted that today, particular importance is acquired in national political systems in the countries with parliamentary and parliamentary-presidential form of state government. The genesis of political parties in Ukraine and abroad is studied: from the times of Antiquity and early Middle Ages to the present. The mission of political parties during the global crisis of liberal democracy in the XXI century is analysed.

The category 'political party' is substantiated in its legal sense, and the main functions of the political parties in Ukraine and abroad are determined and systematized. The institute of state financing of political parties in Ukraine from 2016 to 2019 is analysed. A conclusion is made 
about the tendencies and prospects for the transformation of political parties in Ukraine.

\section{REFERENCES}

1. Achtes Gesetz zur Änderung des Parteiengesetzes vom 29. Juni 2002 // Bundesgesetzblatt. - Teil I. - 2002. - № 42. - S. 2268-2276.

2. Адоратский В. Партия / В. Адоратский // Энциклопедия государства и права ; под ред. П. Стучки, в 3-х томах. - Т. 3. - М. : Изд-во Коммунистической Академии, 1925-1927. - С. 238-248.

3. Барабаш Ю. Нариси з конституційного права / Ю. Г. Барабаш. - Х. : Право, 2012. - 160 с.

4. Богашева Н.В. Відносини держави i політичних партій в Україні: конституційно-правові аспекти : монограф. / Н.В. Богашева. - К. : Логос, 2012. - 446 с.

5. Гаврилишин Б. До ефективних суспільств: Дорога в майбутнє; доповідь Римському Клубові / Б. Гаврилишин ; упорядник В. Рубцов. - Вид. 4-е. К. : Унів. Вид-во ПУЛЬСАРИ, 2013. - 248 с.

6. Гаджиев К.С. Введение в политическую науку / К.С. Гаджиев : учебн. ; изд. 2-е, перераб. и доп. - М. : Издат. корпорац. «Логос», 1997. - 544 c.

7. Демократизация : учебн. пособ. / сост. и науч. ред. : К. В. Харпфер, П. Бернхаген, Р. Ф. Инглхарт, К. Вельцель ; пер. с англ. под науч. ред. М. Г. Миронюка ; предисл., сост. указателя М. Г. Миронюка ; Нац. исслед. ун-т «Высшая школа экономики». М. : Изд. дом Высшей школы экономики, 2015. - 708 с.

8. Дюверже М. Политические партии / М. Дюверже ; пер. с франц. ; изд. 4-е. - М. : Академ. Проект; Трикста, 2007. - 544 с.

9. Кодекс належної практики щодо політичних партій, ухвалений Венеціанською комісією на 77 пленарній сесії (Венеція, 12-13 грудня 2008 р.) // Вибори та демократія. - 2009. - № 4. - С. 84-120.

10. Конституції і конституційні акти України. Історія і сучасність. 3-є вид.; упорядн. І.О. Кресіна, О.В. Батанов ; відп. ред. Ю.С. Шемшученко. - К. : Вид-во «Юридична думка», 2011. - 328 с.

11. Конституція Італійської Республіки (з перед. В. Шаповала) / В. Шаповал. - К. : Москаленко О.М., 2018. - 62 с.

12. Конституція Польської Республіки (з перед. В. Шаповала) / В. Шаповал. - К. : Москаленко О.М., 2018. - 84 с. 
13. Конституція України : прийнята на п'ятій сесії Верховної Ради України 28 червня 1996 року // Відомості Верховної Ради України. 1996. - № 30. - Ст. 141.

14. Майр П. Управляя пустотой: размывание западной демократии / Питер Майр; пер. с англ. Д. Маткиной, А. Новикова, И. Соболевой, В. Степановой. - М.: Изд-во Института Гайдара, 2019. - 216 c.

15. Маніфест європейських патріотів «Європейський дім у вогні». Електронний ресурс. Режим доступу: http://www.ji-magazine.lviv.ua/ 2019/europejskyj-dim-u-vogni.htm - назва 3 екрану.

16. Мелащенко В. Ф. Основи конституційного права України : курс лекцій для студ. юрид. вузів і факультетів / В. Ф. Мелащенко. К. : Вентурі, 1995. - 240 с.

17. Мірчук П. Акт відновлення Української державности 30 червня 1941 року: його генеза та політичне й історичне значення / П. Мірчук. - Ню Йорк : Видання Головної Управи Організації Оборони Чотирьох Свобід України, 1952. - 64 с.

18. Мизес фон Л. Либерализм / Людвиг фон Мизес; пер. с англ. и комментарии А.В. Куряева. - М.; Челябинск: Социум, 2019. - 299 с.

19. НАЗК розподілило кошти на фінасування політичних партій у 2019 році / Офіційний веб-сайт НАЗК. Електронний pecypc. - Режим доступу: https://nazk.gov.ua/news/nazk-rozpodilylokoshty-na-finansuvannya-politychnyh-partiy-u-2019-roci - назва 3 екрану.

20. Осборн Р. Цивилизация. Новая история Западного мира / Р. Осборн ; пер. с англ. М. Колопотина. - М. : Изд-во АСТ, 2018. $768 \mathrm{c}$.

21. Політичні партії / Офіційний веб-сайт Міністерства юстиції України. Електронний ресурс. Режим доступу : https://minjust.gov.ua/ $\mathrm{m} / 4561$ - назва з екрана.

22. Політичні партії в Україні: інформаційно-довідкове видання / Я. Давидович (голова ред. колегіi). - К.: Атіка, 2005. - 440 с.

23. Политические партии мира : энциклопедический справочник ; под общ. ред. Я.А. Пляйса, А.Б. Шатилова. - М. : Полтитическая энциклопедия, 2017. - 535 с.

24. Про внесення змін до деяких законодавчих актів України щодо запобігання і протидії політичній корупції : Закон України від 
8 жовтня 2015 р. // Відомості Верховної Ради України. - 2015. № 49-50. - Ст. 449.

25. Про державну реєстрацію юридичних осіб, фізичних осіб підприємців та громадських формувань : Закон України від 15 травня 2003 р. // Відомості Верховної Ради України. - 2003. - № 31. Ст. 263.

26. Про запобігання корупції : Закон України від 14 жовтня 2014 року // Відомості Верховної Ради України. - 2014. - № 49. Ст. 2056.

27. Про політичні партії в Україні : Закон України від 5 квітня 2001 p. // Відомості Верховної Ради України. - 2001. - № 23. Ст. 118.

28. Снайдер Т. О тирании: 20 уроков XX века / Т. Снайдер; пер. с англ. Н. Охотина. - М. Изд-во АCT : CORPUS, 2018. - 192 с.

29. Совгиря О.В., Шукліна Н.Г. Конституційне право України. Повний курс: навч. посібн. - К.: Юрінком Інтер, 2018. - 556 с.

30. Тодыка Ю. Н. Конституционное право Украины : отрасль права, наука, учебная дисциплина : учебн. пособ. - Х. : «Фолио», «Райдер», 1998. - 292 с.

31. Токвіль А. де. Про демократію в Америці. У двох томах / А. де Токвіль ; пер. $з$ фр. Г. Філіпчука та М. Москаленка : передм. А. Жардена. - К. : Вид. дім «Всесвіт», 1999. - 590 с.

32. Трудным путем демократии: процесс государственного управления в США / К. Джанда, Д.М. Бери, Д. Голдман, К.В. Хула ; пер. с англ. - М. : «Российск. полит. энциклопедия» (РОССПЭН), 2006. $-656 \mathrm{c}$.

33. Федоренко В.Л. Конституційне право України : підручник ; До 20-ої річниці Конституції України та 25-ої річниці незалежності України / В.Л. Федоренко. - К. : Вид-во «Ліра», 2016. - 616 с.

34. Федоренко В.Л. Державне фінансування діяльності політичних партій як чинник розбудови модерної партійнополітичної системи в Україні / В.Л. Федоренко // Вісник НАДУ при Президентові України. Серія «Державне управління».- 2017.№ 4. - С. 35-44.

35. Fedorenko W. Problem ochrony praw człowieka w warunkach rewolucji oraz konfliktów wojennych / W. Fedorenko // Ochrona praw człowieka w wymiarze uniwersalnym. Akcjologia -instytucje- nowe 
wyzwania - praktyka. Red. naukowa J. Jaskiernia, K. Sprzyszak. - Toruń: Wydawnictwo Adam Marszałek, 2017. - S. 73-79.

36. Фінансування політичних партій: український та світовий досвід. Основні тези виступу експерта Центру політико-правових реформ 3 конституційного права, виборів та парламентаризму Богдана Бондаренка / Лівий берег/ Електронний ресурс. - Режим доступу: https://lb.ua/blog/education_assembly/355836_finansuvannya_ politichnih_partiy.html - назва з екрану.

37. Фукуяма Ф. Конец истории и последний человек / Фрэнсис Фукуяма ; пер. с англ. М. Б. Левина. - М. : Изд-во «АСТ», 2015. - $576 \mathrm{c}$.

\section{Information about the authors:}

Fedorenko V. L.

Doctor of Law, Professor,

Director of the Scientific\&Research Center of Forensic Expertise on Intellectual Property of the Ministry of Justice of Ukraine, Honored Lawyer of Ukraine, Forensic Expert of the Higher Qualification Class 26, boulevard 1. Ukrainka, Kyiv, 01133, Ukraine fedorenko900@gmail.com ORCID 0000-0001-5902-1226 